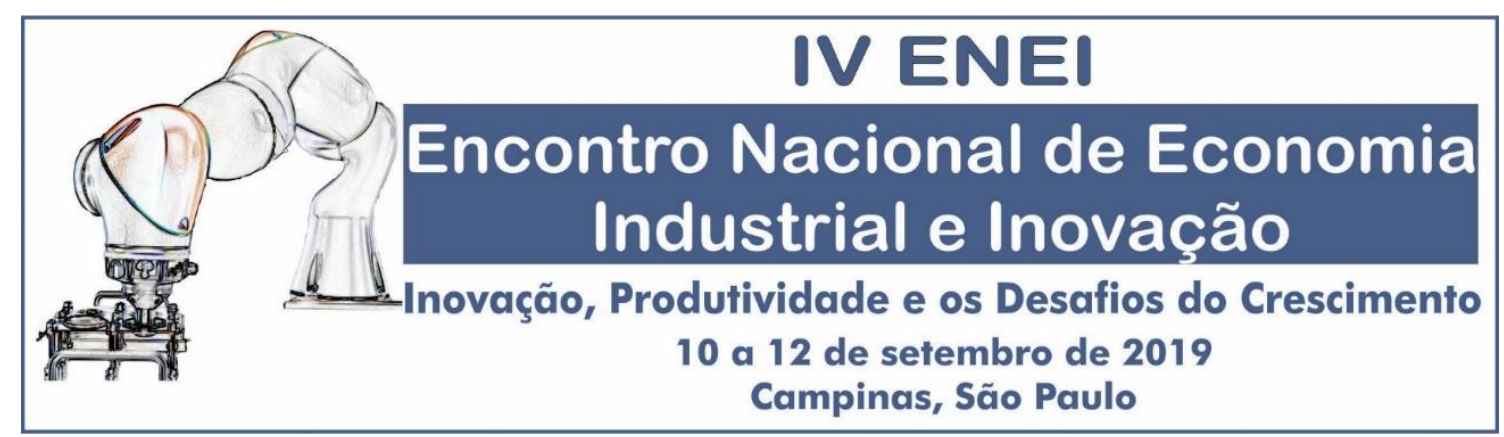

\title{
Grau de adensamento e esgarçamento da estrutura produtiva
}

\author{
Paulo César Morceiro (FEA-USP) ${ }^{1}$ \\ Joaquim José Martins Guilhoto (OCDE e USP) ${ }^{2}$
}

\begin{abstract}
Área ABEIN: 1.1 - Dinâmicas industriais setoriais e dos sistemas de produção
Resumo. A industrialização brasileira por substituição de importações proporcionou níveis elevados de adensamento produtivo, contudo, esses níveis reduziram-se após a abertura comercial. Porém, os estudos existentes utilizaram desagregação setorial que não permite identificar nichos produtivos adensados ou esgarçados dentre dos setores manufatureiros. Este trabalho mapeou e analisou, pela primeira vez para o Brasil, o grau de adensamento produtivo de todas as 258 classes industriais a partir de dados inéditos obtidos do IBGE. Assim, o estudo identificou os nichos mais e menos adensados, possíveis alvos das políticas públicas. Resultados relevam que as classes de baixa e médiabaixa tecnologia continuam predominantemente adensadas, porém, metade das classes industriais de alta e médiaalta tecnologia possui esgarçamento produtivo moderado a elevado, sendo algumas classes tecnológicas já maquiladoras. Conclui-se que o esgarçamento das classes industriais mais tecnológicas pode retardar o desenvolvimento brasileiro, sobretudo quanto à Ciência, Tecnologia e Inovação.
\end{abstract}

Palavras-chave: Adensamento produtivo; desenvolvimento industrial; insumos intermediários; desindustrialização; indústria maquiladora.

\section{Densification degree and productive structure hollowing-out process}

\begin{abstract}
Brazilian industrialization by import substitution provided high levels of productive densification, however, these levels reduced after the trade opening. However, the existing studies used sectoral disaggregation that does not allow the identification of productive niches that are densified or hollowed-out among the manufacturing sectors. This work mapped and analyzed, for the first time for Brazil, the degree of productive densification of all 258 industrial classes based on unpublished data obtained from IBGE. Thus, the study identified the more and less densified niches, possible targets of public policies. Results show that the low and middle-low technology classes are still predominantly densified, but half of the high and medium-high technology industrial classes have moderate to high productive rarefaction, and some technological classes are already maquiladoras. It is concluded that the productive hollowing-out process of the more technological industrial classes can delay the Brazilian development, especially in Science, Technology, and Innovation.
\end{abstract}

Keywords: productive densification; industrial development; intermediate inputs; deindustrialization; maquiladora industry.

Códigos JEL: L6; L16; O14; O54.

\footnotetext{
${ }^{1}$ Doutor em Economia pela FEA-USP. E-mail: paulo.morceiro@gmail.com. O presente trabalho foi realizado com apoio da CAPES e da FIPE. Os autores agradecem a Celso Neris Junior, Luis Gustavo Baricelo e a Milene Simone Tessarin por lerem e comentarem a primeira versão do texto, isentando-os de erros e imprecisões remanescentes.

${ }^{2}$ Economista da OCDE e professor da USP. O conteúdo desta publicação expressa a visão deste autor e não necessariamente representa a visão da OCDE ou dos seus países membros.
} 


\section{Introdução ${ }^{3}$}

Após cinquenta anos de crescimento elevado, desde 1981 a indústria de transformação brasileira vem apresentando estagnação do produto real per capita (MORCEIRO; GUILHOTO, 2019). A partir deste ano, a manufatura começou a crescer abaixo do restante da economia, resultando numa grande diminuição da parcela do valor adicionado manufatureiro (VAM) no Produto Interno Bruto (PIB) mensurado a preços básicos. Entre 1980 e 2018, a parcela do VAM no PIB reduziu-se à metade, de 24,5\% para 11,3\% (MORCEIRO; GUILHOTO, 2019). Dessa forma, o Brasil vem passando por um processo de desindustrialização prematura (CANO, 2012; NASSIF; BRESSER-PEREIRA; FEIJÓ, 2017).

Entre os fatores que explicam a perda de dinamismo do setor manufatureiro estão as importações, principalmente de insumos e componentes, mais competitivas que os produtos domésticos. O comércio internacional é dominado por bens intermediários e, no Brasil, as importações desses itens representam cerca de três quartos do total importado (MIROUDOT, LANZ; RAGOUSSIS, 2009; IBGE, 2016a). Uma parcela da literatura menciona a abertura comercial, ocorrida entre 1988 e 1994, como propagadora da desindustrialização por aumentar os produtos importados na oferta doméstica. Antes da abertura comercial, a economia brasileira era muito protegida por tarifas alfandegárias elevadas e barreiras não tarifárias que restringiam as importações, sobretudo insumos e componentes. Alguns autores diagnosticaram que a abertura comercial foi rápida e profunda (BIELSCHOWSKY, 1999), dessa maneira as empresas domésticas tiveram pouco tempo de adaptação ao cenário mais competitivo (COUTINHO, 1997). Isso resultou num aumento expressivo de importações que substituíram fornecedores nacionais por estrangeiros, conforme dados apresentados por Coutinho (1997) e Moreira (1999). Outra parcela da literatura responsabiliza os episódios de sobrevalorização cambial da segunda metade da década de 1990 e a partir de 2005 por desestimular as exportações e aumentar as importações de insumos e componentes com elevado encadeamento intersetorial e tecnológico (MARCONI; ROCHA, 2012a; SARTI; HIRATUKA, 2018).

Quando o coeficiente de insumos e componentes importados aumenta sem contrapartida da produção industrial, podem-se fragilizar elos produtivos, reduzir os encadeamentos intersetoriais e limitar o desenvolvimento tecnológico, cada vez mais conduzido pelos fornecedores dos componentes principais. Isso pode agravar a desindustrialização ao reduzir a transformação das operações industriais e aumentar as etapas de montagem com uso de mão de obra pouco qualificada e de baixos salários, provocando, desse modo, menor geração de valor adicionado. A literatura tem chamado atenção para isso com os termos especialização regressiva (COUTINHO, 1997), perda de elos da cadeia produtiva (FEIJÓ; CARVALHO; ALMEIDA, 2005; CANO, 2012), rarefação das cadeias produtivas (COMIN, 2009), esgarçamento do tecido industrial (MORCEIRO, 2012), processo de maquilagem (MARCONI; ROCHA, 2012b, 2012a), esvaziamento da estrutura produtiva (CASSIOLATO; FONTAINE, 2015), e desadensamento produtivo (SARTI; HIRATUKA, 2018).

Esses estudos analisaram dados empíricos para no máximo trinta e cinco setores manufatureiros. De modo geral, eles mostraram que dificilmente um setor manufatureiro inteiro encontra-se totalmente desadensado. No entanto, provavelmente, os setores mais rarefeitos devem reunir classes $^{4}$ produtivas muito esgarçadas e outras menos ou até adensadas. Assim, a ótica setorial é inadequada para identificar os segmentos produtivos bem desadensados. Dessa forma, há necessidade de avaliar a indústria de transformação bem desagregada a fim de identificar os segmentos produtivos esgarçados, bem como responder as seguintes perguntas. O país é montador com pouca transformação industrial em alguma classe industrial? Quais as classes industriais com menor e maior grau de adensamento produtivo? O tecido industrial brasileiro ficou mais oco ou rarefeito nos anos 2000? As respostas dessas questões são relevantes para melhor entender a perda de dinamismo da indústria brasileira.

Este trabalho procura mapear e analisar pela primeira vez no Brasil o grau de adensamento produtivo de 258 classes da indústria de transformação brasileira, o qual é mensurado pelo coeficiente importado de insumos e componentes comercializáveis (CIICC). Quanto mais alto esse coeficiente, menos adensado domesticamente. Com isso, busca-se identificar as classes industriais mais esgarçadas pelas importações de

\footnotetext{
${ }^{3}$ Um dos autores elaborou um position paper sobre este assunto para o IEDI com dados mais atualizados (MORCEIRO, 2019).

4 A Classificação Nacional de Atividades Econômicas (CNAE) do Instituto Brasileiro de Geografia e Estatística (IBGE) identifica 24 divisões de atividade manufatureiras ao nível de 2 dígitos de agregação setorial, 103 grupos a 3 dígitos e 258 classes a quatro dígitos - esta última tem o maior detalhamento nas estatísticas de atividades econômicas do Brasil.
} 
insumos intermediários, isto é, os segmentos produtivos mais desindustrializados e com baixo grau de transformação industrial.

O presente estudo teve acesso a dados não publicados da Pesquisa Industrial Anual - Empresa (PIAE) do IBGE, dessa maneira, os dados aqui exibidos são inéditos. Essas informações são essenciais para elucidar as questões colocadas por este trabalho num nível de detalhamento elevado, suprindo uma carência na literatura de estudos que avaliem o segmento industrial mais específico, não apenas as divisões de atividade como é comum nos poucos estudos da área.

Além desta introdução, a seção 2 sintetiza o referencial teórico sobre adensamento produtivo no Brasil e define o esgarçamento produtivo e suas implicações. A seção 3 apresenta as fontes de informações e procedimentos metodológicos. A seção 4 mostra a evolução do CIICC de 24 setores manufatureiros e duas categorias tecnológicas para década do século XXI de maior crescimento industrial desde os anos setenta. A seção 5 mensura o grau de adensamento produtivo para todas as 258 classes industriais organizadas nos setores produtivos, permitindo avaliar com exatidão a extensão do esgarçamento do tecido industrial brasileiro no período recente. A seção 6 exibe e analisa em maior detalhe o quartil das classes industriais mais esgarçado pelas importações de insumos intermediários. A seção 7 conclui.

\section{Referencial teórico}

Esta seção divide-se em duas. A subseção 2.1 explica os termos adensamento e esgarçamento produtivo e suas implicações para o desenvolvimento industrial. A subseção 2.2 sintetiza a bibliografia brasileira sobre esses termos.

\subsection{Ideia de adensamento e esgarçamento produtivo}

Um segmento industrial está conectado, direta e indiretamente, com diversos segmentos produtivos por meio das relações de compras e vendas de matérias-primas, partes, peças, acessórios, componentes e tecnologias. Desse modo, cada segmento está vinculado a uma rede de fornecedores e subfornecedores entrelaçados entre si. Quanto mais longa a cadeia de fabricação de um produto - por exemplo, um automóvel - maior e mais densa será a teia de ligações intersetoriais. Essa rede produtiva é chamada pelos economistas de tecido industrial ou malha manufatureira. Utiliza-se neste trabalho o termo esgarçamento da indústria têxtil para transmitir a ideia de perda de densidade produtiva. Em outras palavras, se os tecidos têxteis não são usados adequadamente, com o tempo se desfiam e se desintegram, podendo inclusive causar buracos e rompimentos. Nessa situação, o tecido encontra-se esgarçado como ilustrado na Figura 1.

Num tecido industrial adensado, os produtores domésticos comercializam a maioria dos insumos e componentes entre eles, mantendo, dessa forma, ligações intersetoriais densas. Ao crescer a demanda por um produto, desencadeia-se uma produção adicional de segmentos a ele conectados na rede produtiva, aumentando também o emprego, a massa salarial, o desenvolvimento tecnológico e a arrecadação tributária.

Figura 1 - Ilustrações de tecido têxtil esgarçado
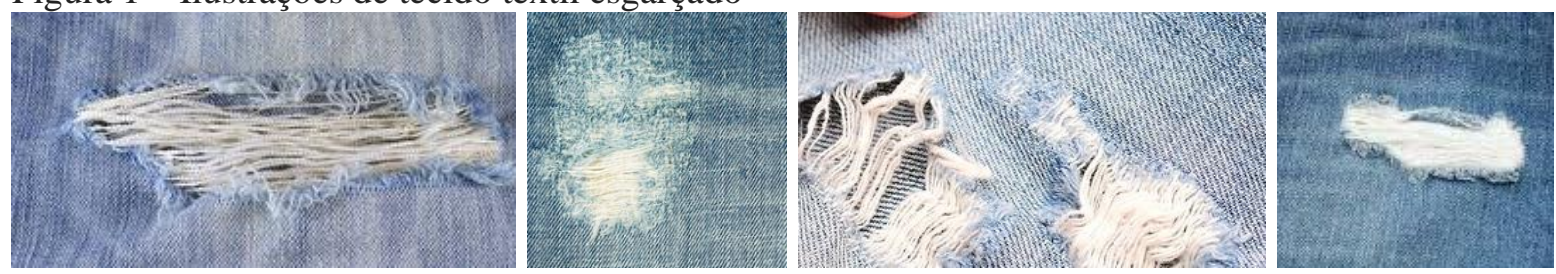

Fonte: Imagens da internet.

Além da demanda derivada decorrente das interdependências da malha produtiva, na medida em que os segmentos industriais vão se adensando eles geram: i) economias externas a la Marshall (1890) para outros segmentos, isto é, transbordamentos e ganhos sinérgicos em termos de tecnologia, mão de obra qualificada, infraestrutura logística e fornecedores especializados; ii) investimentos complementares a la Hirschman (1958); e iii) reduz os custos de produção de produtos novos (HAUSMANN; RODRIK, 2003) e propicia a diversificação produtiva (RODRIK, 2005). Logo, o esgarçamento dos segmentos industriais provoca efeitos contrários aos mencionados, além da diminuição dos encadeamentos intersetoriais. 
Assim, quando se importa a maioria dos insumos e componentes, a rede produtiva fica rarefeita, esburacada ou oca como os tecidos têxteis esgarçados. Uma indústria maquiladora é um exemplo clássico dessa situação, na qual se importam praticamente todos os insumos e componentes comercializáveis, gerando emprego de montagem com salários baixos e pouca contribuição científica e tecnológica para o sistema nacional de inovação (BUITELAAR; PADILLA; URRUTIA, 1999; CASTILLO; DE VRIES, 2018).

Há de se diferenciar baixo adensamento produtivo em estágios iniciais de industrialização daquele de economias industrializadas. De um lado, nos estágios iniciais as importações são essenciais para movimentar as plantas industriais recém-instaladas. O mesmo ocorre com a produção de aviões pela Embraer. Apesar de o Brasil produzir aviões há décadas, ele não conseguiu avançar na produção dos componentes principais como turbinas e aviônica. Dessa maneira, as importações podem gerar a condição para se ter um parque industrial (HIRSCHMAN, 1958, cap. 7). Nesse caso, as importações complementam a produção industrial por incorporar tecnologias de última geração, contribuindo para elevar a competitividade das exportações domésticas. Por outro lado, em economias industrializadas, quando um segmento produtivo muito adensado torna-se rarefeito significa que o tecido industrial deste segmento sofreu um processo esgarçamento, que pode levá-lo à desindustrialização absoluta.

Vale ressaltar que os avanços no adensamento produtivo ocasionaram industrialização em economias retardatárias ao longo dos séculos XIX e XX. O processo inverso, de retrocesso do adensamento em grau intenso pode esgarçar substantivamente o tecido produtivo e ocasionar desindustrialização relativa, conforme explicaram Marconi e Rocha (2012a, 2012b) ou desindustrialização absoluta e/ou tecnológica (SAMPAIO, 2015, p. 76).

Neste estudo adotam-se os termos desadensamento produtivo, rarefação, esvaziamento, desarticulação, fragilização e desintegração com o mesmo sentido de esgarçamento.

\subsection{Adensamento produtivo no Brasil}

Até a década de 1980, a economia brasileira era muito protegida. A parcela dos importados na oferta total de produtos industriais era baixíssima, assim como o percentual importado de insumos intermediários (RAMOS, 1999). ${ }^{5}$ No entanto, esse cenário começou a mudar desde fins da década de 1980 e durante a década de 1990 com a abertura comercial e a estabilização monetária. A redução significativa das barreiras não tarifárias e a diminuição expressiva das tarifas alfandegárias de 1988 a 1994 desencadearam intensas reestruturações industriais, num primeiro momento e, num segundo, modernização produtiva, especialmente após a sobrevalorização cambial a partir de 1994 (CASTRO, 2001). Com isso, ao baratear as importações, por um lado, aumentou a parcela dos importados na oferta doméstica de bens finais e intermediários e, por outro, liberou o consumo reprimido das famílias já majorado pela elevação do poder de compra do Plano Real, pressionando ainda mais as importações.

Coutinho (1997) destacou que os coeficientes de importação (importações sobre a produção) dos setores manufatureiros aumentaram significativamente no período de 1989 a 1996, sobretudo naqueles mais sofisticados, com grau mais elevado de agregação de valor e maior dinamismo tecnológico. Nesses setores - por exemplo, bens de capital, eletrônicos, informática e telecomunicações, especialidades químicas, autopeças e farmacêutica - houve "forte substituição de insumos locais por importados, fechamento de linhas de produção e de unidades fabris inteiras" (COUTINHO, 1997, p. 92), logo, desindustrialização absoluta. $\mathrm{O}$ autor concluiu que nas cadeias industriais mais complexas ocorreu um esvaziamento e uma especialização regressiva do ponto de vista industrial no período pós-estabilização.

Marconi e Rocha (2012a, 2012b) constataram uma substituição de insumos nacionais por importados na economia brasileira durante os períodos de valorização cambial de 1995 a 2008. A partir de testes econométricos em painel, os autores demonstraram que a maior participação dos insumos importados no consumo intermediário da manufatura brasileira está negativamente correlacionada com a parcela da manufatura no PIB no período mencionado, assim o aumento do percentual de insumos importados

\footnotetext{
${ }^{5}$ As importações representaram na oferta dos produtos industriais, respectivamente, 5,8\%, 3,7\% e 4,8\% em 1980,1985 e 1990 . E a parcela dos insumos importados no consumo intermediário total da indústria de transformação foi, respectivamente, 6,4\%, 4,0\% e 3,8\% em 1980, 1985 e 1990. Dados de Ramos (1999, p. 18-19).
} 
contribuiu com a desindustrialização em curso. "Como resultado deste processo, e em função dos resultados obtidos nos testes, é possível argumentar que um processo similar aos das 'maquillas' possa estar ocorrendo no país." (MARCONI; ROCHA, 2012b, p. 5).

Desse modo, ao se manter uma taxa de câmbio sobreapreciada por muito tempo, há riscos de a indústria doméstica se transformar gradualmente numa indústria maquiladora, uma vez que esta taxa torna os insumos e componentes importados mais baratos que os domésticos (BRESSER-PEREIRA; OREIRO; MARCONI, 2015, cap. 7), além de provocar um processo de desindustrialização precoce (MARCONI; ROCHA, 2012a).

A partir de informações anuais das matrizes de insumo-produto estimadas, Morceiro (2012) mensurou o coeficiente importado de insumos e componentes comercializáveis (CIICC), isto é, considerou apenas os insumos intermediários que efetivamente sofrem competição estrangeira. Entre 2000 e 2008, ocorreu um aumento expressivo no coeficiente em vários setores manufatureiros, sendo que, em 2008, nos setores de alta e média-alta tecnologia, o CIICC atingiu o mínimo de 40,7\% e o máximo de 68,6\% (MORCEIRO, 2012, cap. 3). O autor concluiu que houve um esgarçamento no tecido industrial brasileiro com aprofundamento da dependência tecnológica de fornecedores estrangeiros.

Para Sarti e Hiratuka (2018), a desindustrialização da economia brasileira foi agravada no período após a crise internacional de 2008 pelo significativo vazamento de demanda para o exterior, sobretudo de insumos industriais; desse modo, os importados supriram parcela crescente e significativa da demanda doméstica por bens industriais. Os autores exibiram o coeficiente de insumos industriais importados, tabulados pela Funcex-CNI, para os principais setores manufatureiros. A maior parcela de insumos e componentes importados, principalmente aqueles mais elaborados que agregam mais valor e têm maior intensidade tecnológica, causou redução do adensamento produtivo e dos encadeamentos produtivos e tecnológicos na indústria brasileira, bem como corroborou para diminuir a parcela da manufatura no PIB (SARTI; HIRATUKA, 2018). Além disso, eles afirmaram que os bens intermediários ainda têm um peso significativo na estrutura produtiva doméstica, logo, a indústria brasileira não pode ser considerada uma indústria de montagem ou maquiladora. "Mas a tendência em curso é preocupante porque vai nessa direção." (SARTI; HIRATUKA, 2018, p. 145).

No entanto, para outros autores, o tecido industrial brasileiro encontra-se atualmente muito adensado devido à proteção excessiva da economia (PINHEIRO, 2014; CANUTO; FLEISCHHAKER; SCHELLEKENS, 2015).

Pinheiro (2014) usou informações da primeira versão da World Input-Output Database (WIOD) e verificou que apenas $13,5 \%$ do consumo intermediário da indústria de transformação brasileira foi importado em 2011, sendo esse um dos menores percentuais entre os 40 países disponíveis na WIOD. Esse panorama pouco se modificou entre 1995 e 2011. Para o autor, o isolamento da economia doméstica tem reduzido a competitividade das empresas dado seu acesso restrito a insumos intermediários e bens de capital modernos.

Canuto (2014) e Canuto, Fleischhaker e Schellekens (2015) afirmaram que a indústria de transformação brasileira opera com grau de adensamento produtivo muito elevado. Eles observaram que o coeficiente de valor adicionado sobre as exportações de produtos manufaturados foi o mais elevado entre os países cobertos pela base de dados de comércio por valor adicionado da OECD-WTO. A alta parcela do valor adicionado doméstico nas exportações sugere que o Brasil tem ignorado o processo de fragmentação internacional da produção estruturado em CGVs, sendo a Embraer uma exceção. Os autores responsabilizam as políticas comerciais mais protecionistas que a dos parceiros, a infraestrutura logística precária e as exigências de conteúdo nacional pelo elevado adensamento doméstico.

Em síntese, para alguns autores, a estrutura produtiva brasileira sofreu um processo significativo de perda de densidade desde início da década de 1990. Para outros, o tecido industrial ainda é muito adensado devido ao elevado grau de proteção da economia. 


\section{Dados e tratamento das informações}

\subsection{Fonte das informações}

Este estudo teve acesso a uma tabulação especial de informações inéditas da PIA-E do IBGE para todas as classes da indústria de transformação brasileira do período de 1998 a 2014. Essa tabulação englobou as seguintes informações:

a) percentual das compras de matérias-primas, materiais auxiliares e componentes (incluindo material de embalagem, combustíveis usados como matéria-prima e lubrificantes) adquiridos no mercado interno ou importados diretamente, para utilização no processo produtivo;

b) número e percentual das empresas que compram matérias-primas, materiais auxiliares e componentes ou apenas no mercado doméstico ou apenas no exterior ou no mercado doméstico e no exterior.

A vantagem desses dados é que eles captam os bens intermediários realmente consumidos no processo produtivo, não os bens classificados pelo seu uso final como o dos estudos publicados.

Além da tabulação especial, esta pesquisa acessou as informações públicas da PIA-E referentes a valor bruto da produção industrial (VBPI), pessoal ligado à produção, número de empresas e compras de matérias-primas, materiais auxiliares e componentes. $\mathrm{O}$ item (a) equivale ao coeficiente importado de insumos e componentes comercializáveis proposto por Morceiro (2012), porém com a vantagem de ser dez vezes mais desagregado setorialmente.

As informações estão detalhadas no nível de classes industriais para o estrato certo do IBGE, que corresponde a todas as empresas industriais com 30 ou mais pessoas ocupadas e/ou aquelas que tiveram receita bruta proveniente das vendas de produtos e serviços industriais superiores a um valor determinado no ano de referência da pesquisa; em 2015, esse valor foi de $\mathrm{R} \$ 12,8$ milhões. No triênio de 2013-2015, as empresas do estrato certo representaram 96,0\% do VBPI da indústria de transformação; desse modo, as informações deste estudo representam praticamente todo o setor industrial brasileiro.

\subsection{Indicador de adensamento produtivo}

O coeficiente importado de insumos e componentes comercializáveis (CIICC), conforme em (1), será utilizado para mensurar o adensamento produtivo da indústria de transformação como fez Morceiro (2012). Quanto maior o CIICC, menor o adensamento produtivo, e vice-versa.

$\operatorname{CIICC}_{S}(\%)=\left(\frac{I I C C_{S}}{\text { TICC }_{S}}\right) 100$

Em que IICC são as importações de insumos e componentes comercializáveis e TICC o total dos insumos e componentes comercializáveis. O subscrito $s$ indica a classe ou setor industrial. Os insumos e componentes comercializáveis são aqueles que efetivamente sofrem concorrência com o exterior, os quais são produzidos pela agropecuária, indústria extrativa e indústria de transformação. Este estudo utilizou como insumos e componentes comercializáveis as "matérias-primas, materiais auxiliares e componentes (incluindo material de embalagem, combustíveis usados como matéria-prima e lubrificantes)" da tabulação especial da PIA-E.

O CIICC é um indicador mais depurado porque exclui os insumos intermediários pouco ou não comercializáveis com o exterior, os quais são adensados por natureza técnica. Os insumos não/pouco comercializáveis são fornecidos pelos setores de serviços de utilidade pública, construção civil, comércio e serviços. Esses insumos são ofertados majoritariamente por fornecedores domésticos, logo, sofrem pouca pressão competitiva do exterior. Por isso, eles têm um peso baixo nos insumos e componentes importados. De acordo com a matriz de insumo-produto brasileira, com dados de 2010, os insumos e componentes não/pouco comercializáveis representaram apenas $7,1 \%$ de todas as importações de insumos intermediários da indústria de transformação, portanto, 92,9\% das importações de insumos intermediários são de itens comercializáveis. Assim, necessariamente, a análise do grau de adensamento produtivo passa pelos insumos e componentes comercializáveis. 


\subsection{Tratamento dos dados}

Classificação setorial. Até 2007, as informações da PIA-E foram apresentadas na CNAE versão 1.0 e, desde 2007, na CNAE versão 2.0. Uma tabela de correspondência entre a CNAE 1.0 e a CNAE 2.0, fornecida pela Comissão Nacional de Classificação (Concla) do IBGE, foi utilizada para harmonizar eventuais quebras seriais. Com o intuito de perder o mínimo de informação e obter uma identificação praticamente perfeita, as informações de classes industriais da CNAE 1.0 foram convertidas para divisões de atividade da CNAE 2.0.

Período. As informações analisadas correspondem à atividade industrial ao longo de uma década, entre 2003-2004 e 2013-2014. Foram adotados biênios médios para diminuir as oscilações setoriais causadas por diversos eventos. Adotou-se 2003 como a data inicial porque é o primeiro ano antes do crescimento significativo da produção industrial verificado de 2004 a 2013 . O ano de 2014 é o mais recente antes da crise político-econômica brasileira que teve grande repercussão negativa sobre o setor industrial entre 2015-2017.

Comércio exterior. Os dados de exportações e importações fornecidos pelo sistema Alice Web NCM8 foram convertidos para Reais correntes pela taxa de câmbio R\$ / US\$ comercial média mensal do Banco Central do Brasil. Posteriormente, os dados mensais foram agregados em anuais e convertidos para a CNAE 4 dígitos com o auxílio de uma tabela de correspondência NCM-CNAE fornecido pela Concla/IBGE.

Banco de dados. Foi montado um banco de dados para todas as classes da indústria de transformação com informações públicas e da tabulação especial da PIA-E, além das exportações e importações da Alice Web.

Coeficiente importado de insumos e componentes comercializáveis. Para cinco classes industriais ${ }^{6}$ foi aplicada a média de 2012-2014 ao invés de 2013-2014 devido à elevada variação do CIICC em algum dos anos. Como a PIA-E não divulga informações de classes industriais com menos de três empresas pesquisadas, a coleta de dados de duas classes foi modificada. Para a classe 'catalisadores' adota-se a média do triênio dos últimos anos em que há informações disponíveis (2004, 2005 e 2007), ao invés do biênio 2013-2014. Para a classe 'veículos militares de combate' utiliza-se a média das outras classes do setor 'outros equipamentos de transporte'.

Agregação setorial. Adotou-se uma agregação por intensidade tecnológica que divide a indústria de transformação em dois grandes grupos: (i) alta e média-alta tecnologia (AT-MAT) e (ii) baixa e médiabaixa tecnologia (BT-MBT), de acordo com a classificação elaborada pela Organização para a Cooperação e Desenvolvimento Econômico (OCDE). AT-MAT inclui as divisões 20-21 e 26-30 da CNAE 2.0 e BTMBT inclui as divisões 10-19; 22-25 e 31-33. Neste estudo agrupa-se AT com MAT e BT com MBT porque há menor variabilidade das intensidades tecnológicas setoriais no Brasil que nos países da OCDE.

Categorias de uso: Entre as 258 classes industriais é possível verificar, com o auxílio de um tradutor do IBGE, que 117 classes fabricam produtos localizados na ponta final da cadeia - sendo 55 bens de consumo não durável (BCnD), 42 bens de capital (BK) e 20 bens de consumo durável (BCD) -, 126 classes são fornecedoras de insumos intermediários e 15 ofertam serviços industriais (como manutenção, reparação e instalação de M\&Es).

Deflator setorial. Deflatores setoriais ao nível das divisões de atividades foram construídos a partir das Tabelas de Recursos e Usos (TRU) - Referência 2010 da série retropolada do IBGE, que possui informações de 2000 a 2016 para 51 setores de atividade a preços correntes e a preços do ano anterior. Dessa forma, foi empregado o deflator setorial da produção para deflacionar os insumos e componentes nacionais e o deflator setorial das importações para deflacionar os insumos e componentes importados.

\section{Análise do adensamento produtivo setorial nos anos 2000}

Esta seção exibe o CIICC ao nível das divisões de atividade para o Brasil ao longo de uma década, de 2003-2004 a 2013-2014 (Tabelas 1). Entre 2004 e 2013, a produção industrial brasileira apresentou crescimento real de 33,9\% em virtude da forte expansão da demanda doméstica (MORCEIRO, 2018). Desse modo, os dados captam o período de crescimento industrial mais elevado desde a década de 1970.

${ }^{6}$ Códigos CNAE 2.0: 20.21; 26.60; 30.91; 32.20; 33.15. 
Entre os biênios médios de 2003-4 e 2013-4, o CIICC da manufatura brasileira aumentou quase cinquenta por cento, de $16,5 \%$ para $24,4 \%$ (Tabela 1), justificando as preocupações dos estudos que alertaram para a perda de densidade do tecido industrial brasileiro. Setorialmente, a diminuição da densidade produtiva foi generalizada, principalmente entre os setores de AT-MAT. Entre 2003-4 e 2013-4, a categoria de AT-MAT apresentou aumento significativo do CIICC, de 26,3\% para 38,7\%, puxada, sobretudo, pelos setores de informática, eletrônicos e ópticos; máquinas e equipamentos; máquinas e materiais elétricos; outros equipamentos de transportes; e indústria química - setores com aumento de no mínimo 10 p.p. no CIICC. No último biênio, a categoria de AT-MAT apresentou CIICC quase três vezes superior ao da categoria de BT-MBT.

Tabela 1 - Dependência externa de insumos e componentes comercializáveis pelo Brasil

\begin{tabular}{|c|c|c|c|c|c|c|c|c|c|}
\hline \multirow[t]{2}{*}{$\begin{array}{c}\text { Código } \\
\text { CNAE } 2.0\end{array}$} & \multirow[t]{2}{*}{ Descrição } & \multicolumn{2}{|c|}{$\begin{array}{c}\text { CIICC } \\
\text { (a preços } \\
\text { constantes de } \\
2013 / 4)\end{array}$} & \multicolumn{2}{|c|}{$\begin{array}{l}\text { Percentual das } \\
\text { empresas que } \\
\text { compram parcela } \\
\text { dos insumos e } \\
\text { componentes no } \\
\text { exterior } \\
\end{array}$} & \multicolumn{2}{|c|}{$\begin{array}{l}\text { Número de } \\
\text { empresas }\end{array}$} & \multicolumn{2}{|c|}{$\begin{array}{c}\text { Pessoal } \\
\text { ocupado ligado } \\
\text { à produção (em } \\
\text { milhares) }\end{array}$} \\
\hline & & $2003 / 4$ & $2013 / 4$ & $2003 / 4$ & $2013 / 4$ & $2003 / 4$ & $2013 / 4$ & $2003 / 4$ & $2013 / 4$ \\
\hline IT & Indústria de transformação & 16,5 & 24,4 & 18,9 & 19,9 & 28.947 & 37.906 & 3.691 & 5.030 \\
\hline BT-MBT & Baixa e média-baixa tecnologia & 10,8 & 13,6 & 13,3 & 13,9 & 22.838 & 30.534 & 2.781 & 3.767 \\
\hline 10 & Alimentos & 5,3 & 5,1 & 13,0 & 11,0 & 3.348 & 4.613 & 671 & 1.037 \\
\hline 11 & Bebidas & 5,9 & 4,2 & 12,3 & 12,1 & 400 & 459 & 53 & 80 \\
\hline 12 & Fumo & 6,0 & 8,1 & 23,1 & 29,8 & 38 & 33 & 11 & 9 \\
\hline 13 & Têxteis & 10,2 & 18,3 & 24,1 & 26,9 & 1.284 & 1.527 & 207 & 208 \\
\hline 14 & Confecção & 2,1 & 7,4 & 4,6 & 7,1 & 3.527 & 4.907 & 249 & 373 \\
\hline 15 & Calçados e couros & 7,9 & 6,4 & 19,6 & 14,1 & 1.871 & 1.940 & 343 & 291 \\
\hline 16 & Madeira & 3,2 & 7,3 & 5,7 & 6,3 & 1.680 & 1.209 & 154 & 102 \\
\hline 17 & Papel e celulose & 8,5 & 11,2 & 17,9 & 16,1 & 780 & 906 & 106 & 132 \\
\hline 18 & Impressão e reprodução & 27,2 & 17,9 & 17,2 & 16,8 & 324 & 581 & 23 & 45 \\
\hline 19 & Refino de petróleo e álcool & 52,8 & 44,7 & 9,7 & 12,3 & 163 & 221 & 63 & 114 \\
\hline 22 & Borracha e plástico & 9,0 & 19,9 & 20,8 & 23,8 & 2.007 & 2.738 & 211 & 284 \\
\hline 23 & Minerais não-metálicos & 4,1 & 14,1 & 9,9 & 8,8 & 2.080 & 3.178 & 159 & 267 \\
\hline 24 & Metalurgia & 17,2 & 24,4 & 18,1 & 22,2 & 611 & 822 & 142 & 187 \\
\hline 25 & Produtos de metal & 3,4 & 10,1 & 12,4 & 12,9 & 2.293 & 3.441 & 181 & 281 \\
\hline 31 & Móveis & 3,4 & 4,6 & 9,7 & 13,8 & 1.487 & 1.793 & 114 & 157 \\
\hline 32 & Diversos & 14,4 & 22,6 & 26,9 & 29,5 & 687 & 1.121 & 58 & 89 \\
\hline 33 & Manutenção de M\&Es & 18,8 & 35,5 & 12,4 & 11,1 & 264 & 1.049 & 35 & 111 \\
\hline AT-MAT & Alta e média-alta tecnologia & 26,3 & 38,7 & 39,5 & 44,0 & 6.109 & 7.372 & 910 & 1.263 \\
\hline 20 & Química & 30,3 & 40,3 & 46,7 & 46,2 & 1.329 & 1.576 & 144 & 184 \\
\hline 21 & Farmacêutica & 51,9 & 57,3 & 57,6 & 64,5 & 281 & 258 & 41 & 52 \\
\hline 26 & Informática, eletrônicos e ópticos & 57,4 & 75,4 & 57,3 & 63,3 & 639 & 676 & 87 & 108 \\
\hline 27 & Máquinas e materiais elétricos & 9,6 & 26,8 & 38,6 & 40,0 & 729 & 969 & 108 & 182 \\
\hline 28 & Máquinas e equipamentos & 13,8 & 31,9 & 30,4 & 38,8 & 1.906 & 2.455 & 201 & 257 \\
\hline 29 & Automobilística & 19,3 & 25,8 & 31,8 & 39,5 & 1.010 & 1.149 & 282 & 386 \\
\hline 30 & Outros equipamentos de transporte & 43,1 & 54,8 & 31,2 & 43,3 & 217 & 291 & 48 & 94 \\
\hline
\end{tabular}

Nota: Deflator setorial construído a partir das Tabelas de Recursos e Usos. Todas as informações são de empresas com 30 ou mais pessoas ocupadas.

Fonte: Tabulação especial da PIA-E estrato certo do IBGE. Elaboração do autor.

Entre os setores de AT-MAT, o setor automobilístico é o mais adensado e o de informática, eletrônicos e ópticos o menos. O primeiro importou um quarto dos insumos e componentes comercializáveis e, o último, importou três quartos no biênio 2013-4. Neste biênio, os três setores menos adensados são informática, eletrônicos e ópticos; farmacêutica; e outros equipamentos de transporte. Eles possuem elevado potencial de desenvolvimento tecnológico e grande parte dos gastos em pesquisa e desenvolvimento (P\&D) concentram-se nos componentes eletrônicos, nos princípios ativos para a 
fabricação de medicamentos e nos componentes principais dos aviões que o Brasil importa. Dessa maneira, o país é muito dependente de tecnologia embarcada nos insumos e componentes adquiridos do exterior.

Embora a categoria de BT-MBT possua CIICC baixo, três setores apresentaram aumento superior a 10 p.p. e cinco superiores a 5 p.p., e o setor de refino de petróleo ainda continua o menos adensado desta categoria, seguido pela indústria metalúrgica. O país também importa insumos não competitivos nesses dois últimos setores mencionados, isto é, não ofertados por fornecedores domésticos por questões técnicoprodutivas (assunto da próxima seção).

No entanto, o CICC poderia ser muito maior se as empresas instaladas no Brasil mantivessem práticas de importação e processos produtivos atualizados. Apenas duas de cada dez empresas com mais de 30 pessoas ocupadas importaram insumos e componentes no biênio de 2013-4 e não houve modificação nesse cenário em relação ao início da década de 2000 (Tabela 1). Na categoria de BT-MBT, apenas 13,9\% das empresas importaram insumos e componentes para consumo no processo produtivo. O cenário melhora um pouco na categoria de AT-MAT, em que 44,0\% das empresas mantêm práticas de importação de insumos intermediários. Certamente, empresas maiores têm maior propensão a importar que empresas menores (HALPERN; KOREN; SZEIDL, 2015), porém esta pesquisa não teve acesso a informações mais detalhadas por porte. De qualquer forma, poucas empresas brasileiras com mais de 30 funcionários acessaram os insumos intermediários do exterior que geralmente estão na fronteira tecnológica e/ou possuem preços mais competitivos. Será que as oito de cada dez empresas que só adquiriram insumos no mercado doméstico acessaram insumos na fronteira tecnológica de fornecedores domésticos? Ou não precisam acessar fornecedores estrangeiros porque atuam apenas no mercado doméstico protegido das importações? Esse não é o foco deste trabalho, mas, por algum motivo, oitenta por cento das empresas não precisaram importar insumos intermediários para competir nos mercados doméstico e estrangeiro.

Apesar do aumento do CIICC, houve expansão significativa no número de empresas e de pessoas ligadas à produção industrial na maioria dos setores manufatureiros, ou seja, dificilmente houve uma desindustrialização absoluta e generalizada setorialmente. Entre 2004-2013, houve aumento real expressivo do salário mínimo, boom na concessão de crédito, e saldo líquido de 20 milhões de empregos formais. Esses acontecimentos contribuíram diretamente para o crescimento de 55,3\% na demanda total por produtos industriais, que foi parcialmente suprida por produção doméstica (MORCEIRO, 2018). Assim, os empregos ligados às operações fabris da indústria de transformação aumentaram 36\% de 2003/4 a 2013/4, indicando uma expansão absoluta das capacidades de fabricação manufatureira, inclusive nos setores mais fragilizados pelas importações de insumos e componentes. No entanto, há indícios indiretos que a qualidade das ocupações pioraram no período mencionado, com demissões de trabalhadores em todas as faixas salariais superiores a dois salários mínimos e admissões de novos, concentradas nas faixas salariais inferiores a dois salários mínimos (MORCEIRO, 2018). Além disso, vários estudos têm destacado que a produtividade do trabalho da indústria manufatureira diminuiu nos anos 2000 (DE NEGRI; CAVALCANTE, 2014, 2015). Dessa maneira, não pode ser descartada a hipótese de que a manufatura brasileira tem contribuído menos na geração de valor adicionado para o PIB, pois está importando maior percentual de insumos e componentes e aumentando as etapas de montagem com uso de mão de obra pouco qualificada.

A avaliação dos setores manufatureiros realizada aqui ainda é agregada e pode esconder segmentos fragilizados pelas importações de insumos intermediários. As políticas podem ser mais efetivas quando há informações detalhadas. Por isso, nas próximas seções avalia-se o adensamento produtivo com uma lupa dez vezes maior que os setores manufatureiros.

\section{Adensamento produtivo de 258 classes industriais}

A partir desta seção o foco está apenas no biênio 2013-2014. O banco de dados montado para este estudo permitiu o rastreamento das classes industriais de 1998 a 2007 na CNAE 1.0 e, de 2007 a 2014, na CNAE 2.0. Verificou-se que não houve uma substituição absoluta da produção doméstica por importações. Uma evidência real que confirma isso é que o pessoal ligado à produção aumentou na maioria das classes industriais; em apenas um número muito pequeno de classes industriais houve diminuição discreta do emprego. No nível de agregação das classes industriais, é difícil fazer uma comparação para um período 
longo devido à mudança de classificação na CNAE em 2007 e à ausência de deflatores confiáveis para todas as classes industriais.

Mudar a unidade operacional de setores para classes industriais requer alguns cuidados para manter a análise do adensamento produtivo imparcial. Alguns fatores de natureza estrutural e conjuntural podem interferir, positivamente ou negativamente, na importação de insumos e componentes. Primeiro, alguns insumos e componentes são importados porque o país não possui capacidade de produzi-los por motivos técnicos ou escassez de recursos ou tipo de clima, por exemplo, trigo, petróleo leve, alguns metais preciosos, entre outros. Nesses casos, as classes podem ser pouco adensadas devido às importações não competitivas. Segundo, alguns insumos intermediários são pouco comercializáveis, como gases industriais, água para fabricação de bebidas, argila para fabricação de tijolos e cerâmicas, entre outros. Nesses casos, a classe industrial é muito adensada, mas seria adensada independente do grau de proteção comercial e do nível da taxa de câmbio. Sendo assim, o foco desta pesquisa concentra-se nas importações competitivas. Identificar as importações de insumos e componentes não competitivas e as pouco comercializáveis incorreria num trabalho que foge do escopo deste estudo, no entanto, na seção 6, os casos mais evidentes serão mencionados.

A Figura 2 exibe o primeiro mapeamento do adensamento produtivo das 258 classes da indústria de transformação brasileira. As formas geométricas correspondem ao VBPI das classes industriais agrupadas nos seus respectivos setores de origem e em duas categorias tecnológicas. As cores representam o CIICC: as cores branca, cinza e azul claro representam, nessa ordem, as classes industriais mais adensadas, que juntas compõem três quartos do número total de classes; as cores preta, vermelha, laranja e amarela representam as classes menos adensadas, que juntas formam o quartil mais fragilizado pelas importações de insumos e componentes comercializáveis. Para separar esse quartil mais fragilizado de 65 classes industriais, utilizaram-se as matrizes de insumo-produto da World Input-Output Database (WIOD) ${ }^{7}$ para calcular o CIICC médio de 31,2\%, do biênio de 2013-2014, da indústria de transformação dos 15 países que possuem os maiores parques industriais do mundo em 2015, os quais foram ranqueados pelo valor adicionado manufatureiro da Base de Dados de Contas Nacionais das Nações Unidas.

Ao se observar os setores manufatureiros segmentados pelas suas classes industriais, tem-se a aproximação do adensamento da cadeia produtiva daquele setor, pois, geralmente, tanto os fabricantes da ponta final de cadeia (por exemplo, montadoras de automóveis) quanto os de componentes principais (por exemplo, autopeças) fazem parte do mesmo setor de atividade. Assim, a visualização da Figura 2 é bastante intuitiva.

No biênio 2013-2014, a maioria das classes industriais de BT-MBT registra elevado grau de adensamento produtivo, por isso, quase todos os setores de BT-MBT se encontram muito adensados (Figura 2). BT-MBT representa cerca de dois terços da produção industrial brasileira, logo, parcela expressiva do tecido industrial é adensada. Os setores de alimentos, papel e celulose, calçados e couros, madeira, móveis e metalurgia têm elevado adensamento produtivo pois o Brasil possui oferta doméstica competitiva das principais matérias-primas de origem agropecuária e recursos naturais, enquanto os de bebidas e minerais não-metálicos, como era de se esperar, registram um adensamento produtivo elevado, uma vez que seus principais insumos são pouco comercializáveis internacionalmente.

Entre as 162 classes de BT-MBT, apenas 20 estão no primeiro quartil das classes mais fragilizadas pelas importações de insumos e componentes, as quais representaram um quinto da produção industrial de BT-MBT, sendo uma classe do setor de refino de petróleo muito significativa em valor da produção. O setor de refino de petróleo ${ }^{8}$ é o mais fragilizado da categoria de BT-MBT pelas importações, seguido pelo de manutenção de máquinas e equipamentos.

\footnotetext{
${ }^{7}$ Disponível em: http://www.wiod.org/home.

${ }^{8}$ No caso do refino do petróleo, parcela relevante dos insumos utilizados no processo industrial produzidos pela Petrobrás para consumo próprio não entra no CIICC exibido na Figura 2 porque os dados desta pesquisa captam apenas as compras de insumos e componentes comercializáveis pelas classes industriais.
} 
Figura 2 - Mapa do adensamento produtivo da indústria de transformação brasileira no biênio 2013-2014

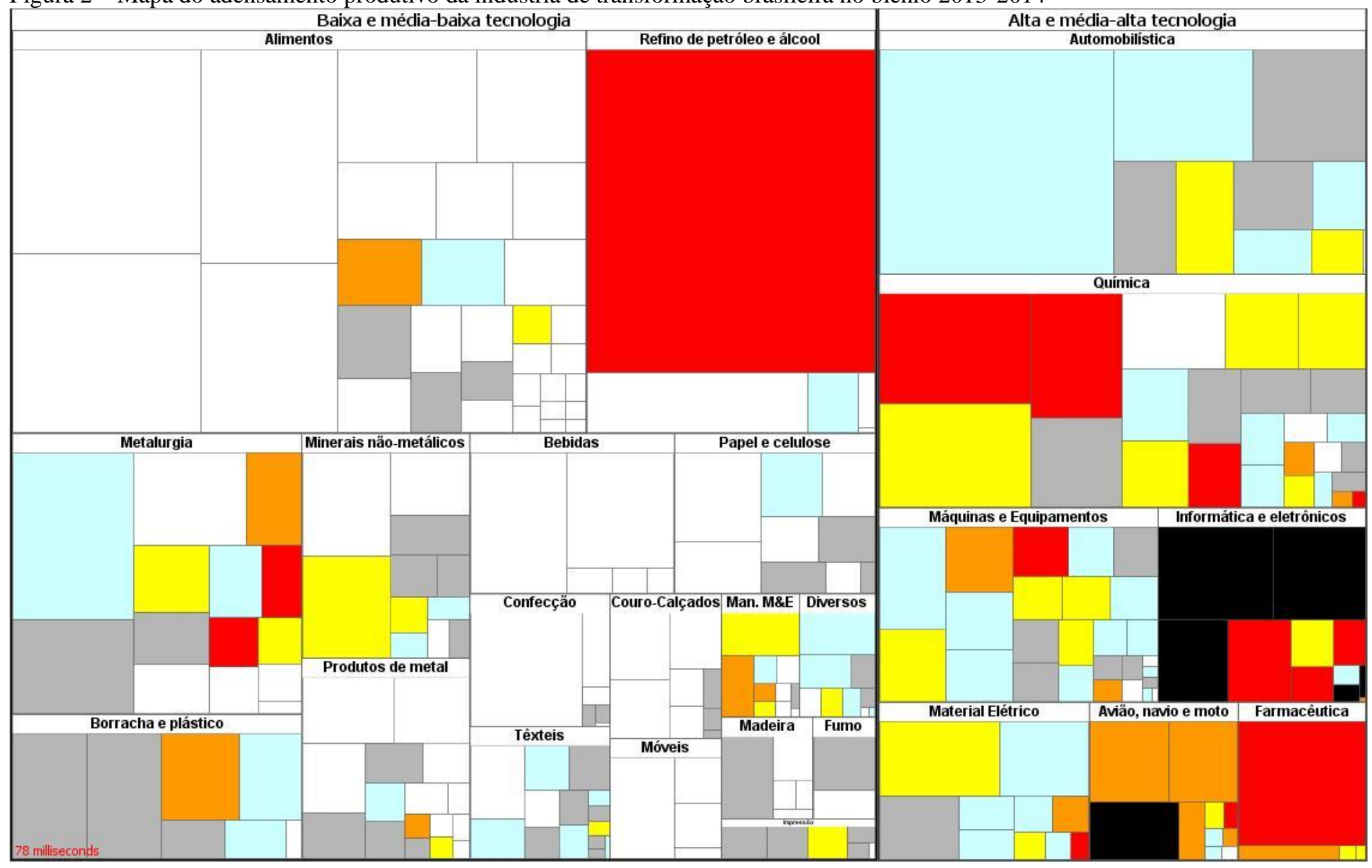

10,1 a $20 \%$

20,1 a $31 \%$

31,1 a $40 \%$

40,1 a $50 \%$

50,1 a $75 \%$

Nota: O tamanho das formas representa o valor bruto da produção industrial (VBPI).

Fonte: Tabulação especial da PIA-E estrato certo do IBGE. Cálculos e elaboração do autor. 
O outro terço do tecido industrial brasileiro encontra-se bem menos adensado. Das 96 classes de AT-MAT, 45 estão no primeiro quartil das classes com maiores CIICC e representam cerca de metade da produção industrial de AT-MAT. O setor de informática, eletrônicos e ópticos é o menos adensado, com várias classes industriais importando mais de três quartos dos insumos e componentes comercializáveis. Também possuem baixo grau de adensamento produtivo os setores farmacêutico e outros equipamentos de transporte (avião, navio e motocicleta). A indústria química, em que algumas classes estão muito adensadas e outras pouco, possui grau de adensamento produtivo moderado. Já nos setores automobilístico, máquinas e equipamentos, e máquinas e materiais elétricos predominam classes com elevado grau de adensamento.

Este estudo foca nos insumos intermediários comercializáveis utilizados nos processos produtivos pela manufatura brasileira, assim, não capta as importações de bens acabados. ${ }^{9} \mathrm{Em}$ um ambiente com taxa de câmbio sobreapreciada por período extenso, pode-se esperar que as empresas primeiro aumentem o conteúdo importado, reduzindo assim o custo de produção, para defender o mercado doméstico contra as importações de bens acabados e, em último caso, passem a importar o produto pronto e revendê-los com etiqueta própria. Se isso ocorreu em alguma medida, durante esse processo, a produção industrial da classe diminuiu e perdeu espaço para as importações no mercado doméstico. As classes industriais reúnem a produção de vários bens (bem final ou intermediário), logo, aquelas mais fragilizadas concentraram a produção nos produtos que ainda compensam a fabricação no Brasil, importando aqueles em que já perderam competitividade. Há evidências de que isso já ocorre em parcela expressiva da manufatura, especialmente de AT-MAT. No biênio 2013-2014, em um quarto das classes de AT-MAT as importações superaram a produção industrial brasileira, portanto, esses segmentos perderam competitividade para os produtos acabados - sejam eles insumos ou bens finais - ofertados em melhores condições pelos fornecedores estrangeiros. ${ }^{10}$ Alguns segmentos chamam atenção pelo expressivo montante monetário importado e a quantidade de vezes que ele superou a produção doméstica, como, por exemplo: a "fabricação de turbinas, motores e outros componentes e peças para aeronaves" teve importações onze vezes superiores ao valor produzido no Brasil; a "fabricação de produtos farmoquímicos" foi oito vezes superior; e a "fabricação de componentes eletrônicos" foi cinco vezes superior.

No mesmo biênio, as importações corresponderam à metade ou mais da produção industrial em $50 \%$ das classes de AT-MAT - no nível setorial, as importações representaram 49,1\% da produção do setor de máquinas e equipamentos, $54,1 \%$ da farmacêutica e $78,1 \%$ de informática, eletrônicos e ópticos, sendo os três setores com maiores percentuais. Desse modo, é provável que houve uma substituição de produção doméstica por importações em algumas classes industriais relevantes na estrutura industrial, sobretudo nos segmentos mais tecnológicos. No entanto, esta pesquisa não teve acesso a informações mais detalhadas para verificar se essa substituição envolveu linhas de produtos inteiras ou parciais, mas provavelmente envolveu parcela expressiva dos produtos fabricados por algumas classes industriais.

Importar produtos acabados em grande quantidade contribui para que alguns setores, especialmente de AT-MAT, sejam pequenos no Brasil comparativamente à economia mundial, sobretudo, informática, eletrônicos e ópticos e a indústria farmacêutica, os quais têm um peso na estrutura industrial brasileira relativamente pequeno se comparados aos países industrializados (UNIDO, 2017, p. 57). ${ }^{11}$ Dessa maneira, várias classes industriais, especialmente de AT-MAT, são potencialmente menores do que poderiam ser dada a demanda doméstica por seus produtos.

Os três parágrafos precedentes dissertaram sobre as importações de bens acabados que, devido à perda de competitividade doméstica, possivelmente contribuíram para o definhamento das capacidades produtivas em várias classes industriais.

A Tabela 2 traz informações adicionais para caracterizar melhor a Figura 2. As faixas mais adensadas encontram-se no topo da tabela e as menos ao seu final. As duas faixas mais adensadas reúnem

\footnotetext{
${ }^{9}$ Entre 2004 e 2013, houve um expressivo vazamento de demanda para o exterior em vários setores manufatureiros, pois a demanda doméstica cresceu muito acima da produção industrial, sendo essa diferença suprida pelas importações de bens finais e intermediários (MORCEIRO, 2018).

${ }^{10}$ Essas informações provêm do banco de dados mencionado na seção 3.

${ }^{11}$ Além disso, esses são os únicos setores em que Brasil não ficou entre os 15 maiores parques industriais do mundo (UNIDO, 2017, p. 57).
} 
146 classes industriais (57\% do total) e são responsáveis por metade da produção industrial, $71 \%$ do pessoal ocupado ligado à produção, $57 \%$ das exportações totais de bens e apenas $21 \%$ das importações totais de bens típicos dessas classes industriais, obtendo um grande saldo comercial. Dessa maneira, as classes industriais que importaram menos de $20 \%$ dos insumos e componentes comercializáveis constituem metade da produção industrial brasileira e apresentam indicadores ainda melhores de geração de empregos, exportações e saldo comercial.

As últimas quatro faixas menos adensadas representam o quartil mais fragilizado pelas importações de insumos e componentes comercializáveis, que é composto por 65 classes industriais responsáveis por $31,4 \%$ da produção industrial e 15,2\% do pessoal ocupado ligado à produção, ou seja, quartil de elevada produtividade do trabalho (produção por trabalhador). Além disso, essas quatro faixas apresentam intensidade elevada tanto nas importações de insumos e componentes comercializáveis quanto no total de bens importados. Apesar de terem um peso de 28,5\% no total de insumos e componentes comercializáveis consumidos no processo produtivo pela indústria de transformação, o quartil mais fragilizado foi responsável por $62,6 \%$ dos insumos e componentes comercializáveis importados. No caso das importações de todos os produtos da indústria de transformação, que inclui os bens acabados, esse quartil foi responsável por metade dessas importações. As exportações dessas 65 classes foram inferiores às importações de insumos e componentes comercializáveis utilizados no processo produtivo, gerando um déficit expressivo de R \$ 75,7 bilhões correntes no biênio 2013-2014. Isso ilustra uma dependência estrutural da economia brasileira por importações de insumos intermediários e, também, por bens finais de produtos típicos das 65 classes que apresentam o tecido produtivo mais desadensado.

Tabela 2 - Características das faixas de adensamento produtivo da Figura 2, 2013-2014

\begin{tabular}{|c|c|c|c|c|c|c|c|c|}
\hline $\begin{array}{l}\text { Coeficiente } \\
\text { importado de } \\
\text { insumos e } \\
\text { componentes } \\
\text { comercializávei } \\
\text { s }\end{array}$ & $\begin{array}{c}\text { Número } \\
\text { de classes } \\
\text { industriai } \\
\mathrm{s}\end{array}$ & $\begin{array}{c}\text { Valor } \\
\text { bruto da } \\
\text { produçã } \\
\text { o } \\
\text { industria } \\
1(\%)\end{array}$ & $\begin{array}{l}\text { Pessoal } \\
\text { ocupada } \\
\text { ligado à } \\
\text { produçã } \\
\text { o }(\%)\end{array}$ & $\begin{array}{c}\text { Total de } \\
\text { insumos e } \\
\text { componentes } \\
\text { comercializávei } \\
\text { s (\%) }\end{array}$ & $\begin{array}{c}\text { Insumos e } \\
\text { componentes } \\
\text { comercializávei } \\
\text { s importados } \\
(\%)\end{array}$ & $\begin{array}{c}\text { Exportaçõe } \\
\text { s de bens } \\
(\%)\end{array}$ & $\begin{array}{c}\text { Importaçõe } \\
\text { s de bens } \\
(\%)\end{array}$ & $\begin{array}{c}\text { Exportações } \\
\text { menos } \\
\text { importações de } \\
\text { insumos e } \\
\text { componentes } \\
\text { comercializávei } \\
\text { s (bilhões de } \\
\text { R\$) }\end{array}$ \\
\hline 0 a $10 \%$ & 91 & 35,7 & 51,1 & 36,3 & 5,7 & 46,8 & 8,3 & 137,7 \\
\hline 10,1 a $20 \%$ & 55 & 14,2 & 19,4 & 14,4 & 9,1 & 10,1 & 12,8 & 8,2 \\
\hline 20,1 a $31 \%$ & 47 & 18,7 & 14,3 & 20,8 & 22,6 & 14,3 & 29,0 & $-14,7$ \\
\hline 31,1 a $40 \%$ & 28 & 8,9 & 7,0 & 9,0 & 13,0 & 10,5 & 15,7 & $-0,9$ \\
\hline 40,1 a $50 \%$ & 17 & 4,3 & 3,4 & 5,1 & 9,2 & 7,1 & 5,1 & $-1,8$ \\
\hline 50,1 a $75 \%$ & 14 & 15,2 & 3,4 & 10,7 & 27,5 & 8,4 & 22,3 & $-47,1$ \\
\hline 75,1 a $100 \%$ & 6 & 3,0 & 1,4 & 3,8 & 13,0 & 2,9 & 6,9 & $-25,9$ \\
\hline Total & 258 & 100,0 & 100,0 & 100,0 & 100,0 & 100,0 & 100,0 & 55,5 \\
\hline 31,1 a $100 \%$ & 65 & 31,4 & 15,2 & 28,5 & 62,6 & 28,9 & 50,0 & $-75,7$ \\
\hline
\end{tabular}

Fonte: PIA-E, tabulação especial da PIA-E estrato certo e Alice Web. Cálculos e elaboração do autor.

Em síntese, a maioria das classes industriais encontra-se com grau de adensamento produtivo elevado, sobretudo de BT-MBT. Um número reduzido de classes industriais, especialmente dos setores mais tecnológicos, possui estrutura produtiva pouco adensada e as importações brasileiras de insumos intermediários e bens finais concentram-se nessas classes, assim como o déficit comercial. A próxima seção exibe em detalhe as 65 classes menos adensadas.

\section{Adensamento produtivo das classes industriais mais esgarçadas}

O Gráfico 1 exibe o quartil das classes industriais mais fragilizadas pelas importações de insumos intermediários comercializáveis, isto é, as classes que possuem CIICC acima de 31,2\% (média da indústria de transformação dos 15 países manufatureiros líderes). Na parte superior do Gráfico 1 estão as 45 classes de AT-MAT que representaram 47,6\% de toda a produção industrial de AT-MAT e, na parte inferior, as 20 classes de BT-MBT que corresponderam a 21,9\% da produção industrial de BT-MBT. 
Note que as classes de AT-MAT possuem CIICC bem maiores que as classes de BT-MBT. Isso é preocupante tendo em vista que as indústrias de AT-MAT contribuem sobremaneira para o desenvolvimento tecnológico, empregam mão de obra qualificada e pagam salários elevados comparativamente às indústrias de BT-MBT, e também tendem a crescer mais rápido devido à maior elasticidade-renda da demanda e maior dinamismo no comércio internacional.

Entre as 65 classes industriais do Gráfico 1, 32 são classificadas como bens intermediários (BI), 16 bens de capital (BK), 8 bens de consumo durável (BCD), 5 bens de consumo não-duráveis (BCnD) e 4 sem classificação (correspondem ao setor de manutenção, reparação e instalação de M\&Es). Ou seja, bens intermediários compõem uma metade e bens finais a outra. Geralmente, bens finais têm cadeias produtivas mais longas que bens intermediários, dessa maneira, quando as classes de bens finais importam elevado percentual de insumos e componentes, provavelmente reduzem-se (ou extinguem-se) os fornecedores domésticos a sua montante da cadeia de produção. Então, do ponto de vista do adensamento produtivo, a situação é mais grave quando a classe industrial que possui CIICC elevado produz bens mais próximos da ponta final da cadeia produtiva.

Para facilitar a exposição, as classes foram agrupadas por divisão de atividade e algumas análises são concentradas naquelas maiores e mais fragilizadas.

O setor de informática, eletrônicos e ópticos é o mais esgarçado. Das 11 classes do setor, dez estão exibidas no Gráfico 1, as quais representaram $98,6 \%$ da produção industrial do setor. Oito classes produzem bens finais (cinco BCD e três BK) e duas bens intermediários, logo, o setor possui cadeias produtivas longas, porém os encadeamentos são fracos devido ao CIICC elevado.

“Aparelhos telefônicos e outros equipamentos de comunicação" importou 93,2\% do total dos insumos e componentes comercializáveis, sendo esta a classe mais esgarçada do tecido industrial brasileiro. Assim, a cadeia de suprimento doméstica é reduzidíssima. As classes "equipamentos e instrumento ópticos, fotográficos e cinematográficos", "cronômetros e relógios", "aparelhos de recepção, reprodução, gravação e amplificação de áudio e vídeo" e "periféricos para equipamentos de informática" importaram mais de $75 \%$ dos insumos e componentes comercializáveis. Do ponto de vista do grau da transformação industrial, dois terços do setor de informática, eletrônicos e ópticos não apresentam diferenças significativas de uma indústria maquiladora e o outro terço está bem próximo disso. ${ }^{12} \mathrm{O}$ emprego do termo indústria maquiladora nesse contexto refere-se apenas aos processos produtivos em que predominam operações de montagem a partir de insumos e componentes importados e uso de mão de obra mais barata do que seria se houvesse maior transformação industrial. ${ }^{13}$ A produção relevante de informática, eletrônicos e ópticos é regulada no âmbito da Lei de Informática e da Zona Franca de Manaus, as quais concedem vários benefícios fiscais e exigem como contrapartida o cumprimento de um processo produtivo básico (PPB) para cada produto fabricado e a aplicação de 5\% do faturamento em P\&D. Porém, o PPB pode ser cumprido com operações fabris mínimas como soldagem, pintura, montagem, usinagem, colagem, grampeamento e integração de componentes. Essas tarefas agregam pouco valor em comparação com as que fabricam os componentes principais.

A farmacêutica é o segundo setor mais desarticulado pelas importações e todas as suas quatro classes são exibidas no Gráfico 1. A principal delas, "medicamentos para uso humano", representa 90\% da produção industrial do setor e importou $58,9 \%$ dos insumos intermediários comercializáveis. O país importa, principalmente, o princípio ativo farmoquímicos e adjuvantes farmacotécnicos para a fabricação dos medicamentos por estratégia de suprimento das empresas que priorizam insumos mais elaborados e competitivos do exterior (GOMES et al., 2014; PINTO, 2014). O princípio ativo é o composto responsável pela ação ou efeito farmacológico do medicamento, sendo o resultado principal da pesquisa científica e tecnológica das empesas farmacêuticas. A indústria farmacêutica é estratégica para a segurança nacional em termos de saúde pública e ela ficará mais relevante à medida que a população envelhece, logo, tende a ser mais importante ainda no futuro. Assim, a manutenção do grau de desadensamento elevado incorrerá em aumento persistente das importações.

\footnotetext{
${ }^{12}$ Nesse setor, o México, país que possui uma indústria maquiladora relevante, importou 81,4\% dos insumos e componentes comercializáveis, conforme cálculos próprios a partir das matrizes de insumo-produto da WIOD.

${ }^{13} \mathrm{~A}$ indústria brasileira de informática, eletrônicos e ópticos difere da maquila mexicana ao exportar pouco.
} 
Gráfico 1 - Percentual importado de insumos e componentes comercializáveis das 65 classes industriais menos adensadas da manufatura brasileira, média 2013-2014

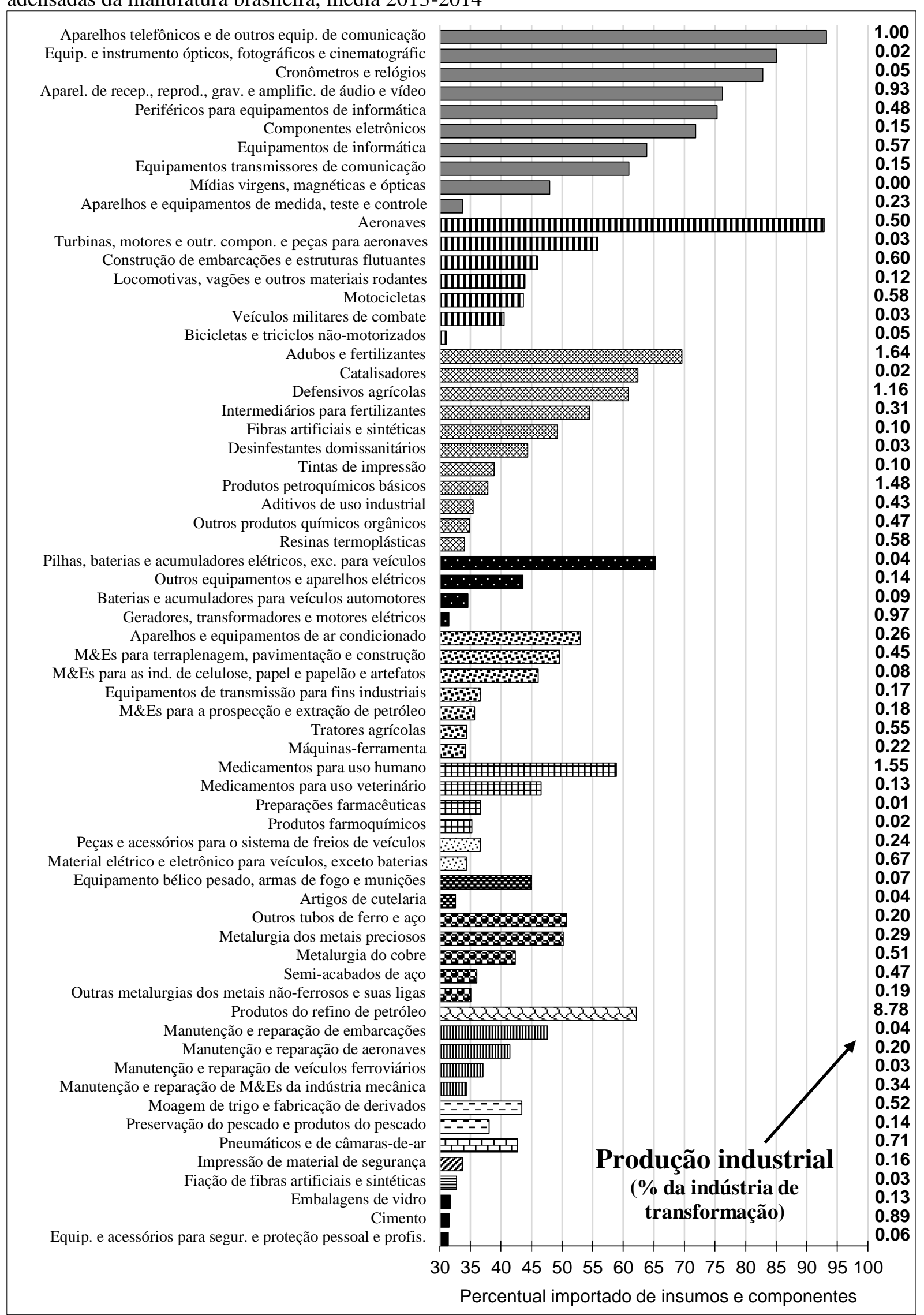

Fonte: Tabulação especial da PIA-E estrato certo do IBGE. Elaboração do autor. 
Outros equipamentos de transporte é o terceiro setor mais desarticulado. Ele reúne a produção de aeronaves, embarcações navais, motocicletas e equipamentos ferroviários, os quais são essencialmente bens finais (BK e BCD). As sete classes exibidas no Gráfico 1 representaram 96,3\% do VBPI do setor. A classe "aeronaves" importou 92,8\% de todos os insumos e componentes comercializáveis, sendo a segunda classe mais oca da indústria brasileira. O Brasil possui uma empresa relevante, a Embraer, no segmento de aviação regional. Como são importados os componentes principais, praticamente toda a cadeia de fornecedores dos aviões encontra-se no exterior. Assim, do ponto de vista do adensamento produtivo, a classe "aeronaves" é uma maquila típica que importa insumos e componentes e exporta o bem final. Mas cabe uma ressalva. Geralmente o que caracteriza as maquilas, além do baixo grau de adensamento produtivo, é a utilização de mão de obra de baixa qualificação e remuneração. Nesse aspecto, a Embraer não pode ser considerada uma maquila porque emprega mão de obra de elevada remuneração, já que a montagem de aeronaves envolve protocolos de segurança que exigem profissionais altíssima qualificação. Ademais, ela lidera a sua cadeia produtiva ao desenhar os aviões, gerencia a cadeia de suprimento e comercializa suas aeronaves, tarefas que lhe possibilita capturar uma fatia do valor agregado maior do que seria no caso de uma maquila típica. Entretanto, ao importar os componentes principais, vaza para o exterior grande parte do desenvolvimento científico e tecnológico possível de ser desenvolvido pelos fornecedores dessa classe industrial.

Com o renascimento da indústria naval, desde início dos anos 2000, a classe "construção de embarcações e estruturas flutuantes" é a segunda mais expressiva em VBPI. Ela importou 45,9\% dos insumos e componentes comercializáveis, provavelmente aqueles mais tecnológicos das plataformas marítimas de petróleo e sondas de perfuração submarina. Esses produtos passaram a ser parcialmente fabricados no país devido ao requerimento de conteúdo local exigido nos investimentos, no Brasil, pelas operadoras petrolíferas. No entanto, a legislação petrolífera ${ }^{14}$ permite que se importe parcela relevante dos componentes principais das embarcações.

A fabricação de motocicletas utiliza proporção razoável de insumos e componentes comercializáveis importados. Por se tratar de um produto que o Brasil possui domínio tecnológico e grande mercado consumidor, essa situação é preocupante devido à perda de competitividade no preço dos insumos e componentes.

O setor de químico é o quarto mais fragilizado pelas importações e possui 11 das 65 classes industriais representadas no Gráfico 1, que corresponderam a 62,7\% da produção industrial do setor. Ele produz majoritariamente insumos intermediários para serem consumidos pelos demais setores, especialmente a própria indústria de transformação, agricultura, construção civil e saneamento básico. As classes "adubos e fertilizantes", "defensivos agrícolas" e "intermediários para fertilizantes" importaram, respectivamente, $69,6 \%, 60,8 \%$ e $54,5 \%$ do total dos insumos e componentes comercializáveis e juntas representam cerca de um terço da produção química. O país tem uma dependência externa elevada de fertilizantes químicos, já que importa cerca de $60 \%$ dos fertilizantes que consome (COSTA; SILVA, 2012). Entre os três principais fertilizantes demandados, o Brasil importou 90\%, 76\% e 41\%, respectivamente, dos fertilizantes potássicos, nitrogenados e fosfatados consumidos, em 2010 (COSTA; SILVA, 2012, p. 37 41). No caso dos potássicos, existem grandes reservas na Amazônia que não são economicamente viáveis e oferecem grandes riscos ambientais; em relação aos nitrogenados, o preço do gás natural, principal matéria-prima, é superior ao praticado no mercado internacional; e quanto aos fosfatados, o país não possui produção satisfatória de enxofre, matéria-prima básica do ácido sulfúrico utilizado para obter o ácido fosfórico, que é um intermediário dos fertilizantes fosfatados (COSTA; SILVA, 2012). Dessa maneira, uma parcela dessas importações é pouco competitiva. Como o uso de fertilizantes químicos foi vital à elevação da produtividade agrícola brasileira desde 1990 (COSTA; SILVA, 2012, p. 31) e a agricultura doméstica tem contribuído bastante para fechar o balanço de pagamentos, melhorar a oferta doméstica de fertilizantes garantirá um futuro sustentável à produção agrícola e contribuirá para evitar restrições de divisas estrangeiras.

\footnotetext{
${ }^{14}$ Desde 2005, um conteúdo local mínimo (CLM) é exigido nos contratos entre operadoras petrolíferas e a Agência Nacional de Petróleo (ANP). A empresa vencedora da licitação tem que cumprir um CLM para vários equipamentos utilizados nas etapas de exploração e desenvolvimento do bloco de petróleo (ANP, 2013, p. 165). Em geral, o CLM é baixo para componentes tecnológicos, que mesmo sendo importados atingem o CLM com operações locais de montagem, usinagem e pintura.
} 
Nota-se que os quatro setores com baixo grau de adensamento produtivo são extremamente relevantes para o desenvolvimento tecnológico mundial (GALINDO-RUEDA; VERGER, 2016, p. 10). O setor de informática, eletrônicos e ópticos e a indústria farmacêutica foram responsáveis, respectivamente, por $24,0 \%$ e $22,1 \%$ dos gastos em P\&D das 1.000 maiores empresas que mais investiram em P\&D em 2016 (JARUZELSKI; STAACK; SHINOZAKI, 2016), sendo os dois principais setores que mais investem em ciência e tecnologia com finalidade comercial no planeta. Nos Estados Unidos, em 2014, o primeiro setor realizou $21,7 \%$ de todos os gastos empresariais em $P \& D$, a indústria farmacêutica $16,6 \%$, o setor de outros equipamentos de transportes $8,3 \%$ e a indústria química $2,8 \%$, logo, esses quatro setores foram responsáveis por metade dos gastos empresariais em P\&D estadunidense e por três quartos da P\&D investida pela indústria de transformação, conforme cálculos do autor a partir da OECD-ANBERD Database (2017). Desse modo, o ritmo do desenvolvimento tecnológico mundial depende bastante dos investimentos em $\mathrm{P} \& \mathrm{D}$ desses quatro setores.

Assim, da perspectiva tecnológica, o baixo grau do adensamento produtivo tem consequências ruins para o sistema nacional de inovação. A principal delas é o baixo gasto em P\&D realizado pelas empresas brasileiras comparativamente às dos países líderes. Em 2014, o esforço tecnológico - P\&D dividido pela receita líquida de vendas ou pelo valor da produção - brasileiro foi apenas uma fração pequena do realizado pelos Estados Unidos nos quatro setores acima mencionados. ${ }^{15}$ A industrialização brasileira ocorreu com forte presença das filiais de empesas transnacionais (ETNs), sobretudo nos setores mais tecnológicos, que operam com alto índice de importação de insumos e componentes tecnológicos (CASSIOLATO; SZAPIRO; LASTRES, 2015). Os dados exibidos pelos autores confirmam que as filiais de ETNs têm tido fraco desenvolvimento tecnológico no Brasil (CASSIOLATO; FONTAINE, 2015) comparativamente ao realizado pelas matrizes nos países-sede (TESSARIN, 2018). Da mesma forma, também têm consequências ruins para o emprego de mão de obra qualificada e bem remunerada, seja nos laboratórios empresariais de pesquisas científicas e tecnológicas, seja no próprio chão de fábrica ao exigir dos trabalhadores tarefas mais simples e de menor habilidade cognitiva. Outra implicação negativa direta do menor grau de adensamento produtivo refere-se às ligações intersetoriais. Os multiplicadores de produção ${ }^{16}$ dos quatro setores foram inferiores à média de 2,13 registrada pela indústria de transformação brasileira, sendo que os setores de informática, eletrônicos e ópticos e farmacêutico possuem os menores multiplicadores da manufatura, respectivamente, de 1,68 e 1,69 (IBGE, 2016a). Isso significa que o tecido industrial está esburacado pelas importações de insumos e componentes, especialmente no setor de informática, eletrônicos e ópticos, que possui cadeia produtiva bem longa.

Os setores de máquinas e equipamentos, máquinas, aparelhos e materiais elétricos e automobilístico foram os mais adensados da indústria de AT-MAT. As classes muito fragilizadas pelas importações de insumos e componentes são poucas. No geral, esses setores possuem cadeias produtivas longas pois os principais produtos são bens finais compostos de muitas partes, peças e componentes. No entanto, em sessenta por cento das classes de 'máquinas e equipamentos' e 'máquinas, aparelhos e materiais elétricos' as importações representaram 50\% ou percentual superior da produção doméstica, conforme mencionado antes - o país perdeu competitividade em parte dos produtos acabados que antes tinham domínio tecnológico e preço competitivo, logo a estratégia de substituir insumos e componentes domésticos por importados tem limite.

Com exceção do refino de petróleo, os setores de BT-MBT possuem poucas classes desadensadas pelas importações de insumos e componentes, as quais têm um peso relativamente pequeno no valor da produção setorial. A classe "produtos do refino de petróleo" importou 62,1\% dos insumos e componentes comercializáveis, sendo o maior percentual das classes de BT-MBT. Vale mencionar novamente que nesta classe parcela relevante dos insumos utilizados no processo industrial produzidos pela Petrobrás para

\footnotetext{
${ }^{15}$ Em 2014, o esforço tecnológico brasileiro no setor de informática, eletrônicos e ópticos foi de apenas 8,8\% do realizado pelos Estados Unidos; na farmacêutica, de apenas 9,2\%; nos outros equipamentos de transportes, de apenas 26,8\%; e na indústria química, de 45,1\%, conforme cálculos do autor a partir de várias fontes (PINTEC, 2016; OECD-ANBERD DATABASE, 2017; OECD-STAN DATABASE, 2018).

${ }^{16} \mathrm{O}$ multiplicador da produção mede o quanto se gera de produção doméstica adicional a partir do aumento de uma unidade monetária na demanda final.
} 
consumo próprio não entra no CIICC exibido no Gráfico 1 pois os dados desta pesquisa captam apenas as compras de insumos e componentes comercializáveis pelas classes industriais e não levam em consideração o consumo intermediário para consumo próprio. ${ }^{17}$ Essa classe representou $8,78 \%$ da produção industrial brasileira, sendo a maior de todas. Ela fabrica produtos como gasolina, querosene de aviação, óleo diesel e diversos insumos para a indústria química como a nafta, daí sua importância na estrutura produtiva manufatureira. O Brasil importa petróleo mais leve que o produzido domesticamente para refinar, pois não possui capacidade de produção do óleo leve, na quantidade requerida, por escassez desse recurso no território doméstico. Nesse caso, trata-se de importações não competitivas que vêm complementar a insuficiente produção doméstica de óleo de excelente qualidade. O país também importa alguns insumos derivados do petróleo em volume expressivo.

Nas indústrias de BT-MBT existem casos de importações não competitivas que o país convive há várias décadas, como nas classes "moagem de trigo e fabricação de derivados", "metalurgia dos metais preciosos", "metalurgia do cobre", "impressão de material de segurança", "pneumáticos e câmaras-de-ar" e "cimento". Alguns insumos e componentes relevantes dessas classes não têm capacidade de produção doméstica na quantidade e qualidade demandadas, principalmente devido à escassez de recursos naturais, matérias-primas e ao clima pouco favorável à produção desses itens no Brasil. Desse modo, são poucas as classes de BT-MBT desarticuladas por importações competitivas.

Em resumo, as empresas brasileiras de várias classes industriais, sobretudo de elevada intensidade tecnológica, importaram um percentual elevado de insumos intermediários comercializáveis. Dessa maneira, as cadeias produtivas que produzem os produtos mais elaborados encontram-se esgarçadas e com encadeamentos intersetoriais fracos. Ademais, as importações não competitivas foram as principais responsáveis pelos poucos segmentos mais desarticulados de BT-MBT. No entanto, as importações são indispensáveis à produção de qualquer país e é difícil saber se o país produziria com a mesma eficiência se importasse menos.

\section{Considerações finais}

Atualmente, os processos produtivos são mais fragmentados que no passado, desse modo, o desenvolvimento tecnológico incorporado nos insumos e componentes e os encadeamentos intersetoriais são maiores. Quando o coeficiente importado de insumos e componentes comercializáveis (CIICC) aumenta sem contrapartida da produção, pode-se fragilizar elos produtivos, reduzir os encadeamentos intersetoriais e limitar o desenvolvimento tecnológico que é cada vez mais conduzido pelos fornecedores dos componentes principais. Isso pode agravar a desindustrialização ao reduzir a transformação das operações industriais e aumentar as etapas de montagem com uso de mão de obra pouco qualificada e de baixos salários, provocando, desse modo, menor geração de valor adicionado. A literatura tem chamado atenção para as causas e impactos da diminuição de densidade do tecido industrial brasileiro desde a década de 1990 (COUTINHO, 1997; FEIJÓ; CARVALHO; ALMEIDA, 2005; COMIN, 2009; CANO, 2012; MORCEIRO, 2012; MARCONI; ROCHA, 2012a, 2012b; CASSIOLATO; FONTAINE, 2015; SARTI; HIRATUKA, 2018). Este estudo contribui com essa literatura ao realizar uma avaliação empírica inédita do adensamento produtivo para 258 classes da indústria de transformação brasileira, assim, adota uma desagregação setorial no mínimo sete vezes maior que os estudos precedentes.

A partir de informações oficiais inéditas obtidas do IBGE, o adensamento produtivo foi mensurado pelo CIICC para captar os insumos intermediários que efetivamente sofrem competição com o exterior. Assim, quanto maior o CIICC menor serão as ligações intersetoriais e o desenvolvimento tecnológico domésticos por unidade de produção industrial. As principais considerações a partir das evidências empíricas encontram-se a seguir.

Primeiro, a manufatura brasileira apresentou uma diminuição significativa do adensamento produtivo na década do século XXI de maior crescimento industrial após os anos setenta. No entanto, o retrocesso no adensamento não provocou desindustrialização absoluta das classes industriais, pois estas não

\footnotetext{
${ }^{17}$ Dados da ANP informam que do total do petróleo refinado no Brasil, cerca de $3 / 4$ foram produzidos domesticamente no biênio 2013-2014. Vale salientar que o CIICC também leva em consideração outros insumos além do petróleo. Apesar isso, o CIICC seria, certamente, menor se fosse levado em conta o petróleo produzido pela Petrobras para consumo próprio.
} 
apresentaram diminuição do emprego ligado as operações industriais. Certamente, o crescimento industrial do século XXI ocorreu com menor transformação industrial e maior uso de mão de obra pouco qualificada ligada as operações de montagem de insumos e componentes importados, fato que corrobora para a diminuição da parcela manufatureira no PIB conforme apontaram Marconi e Rocha (2012a, 2012b) e Sarti e Hiratuka (2018).

Segundo, a indústria de transformação brasileira ainda possui grau de adensamento produtivo alto, sobretudo porque os setores manufatureiros de baixa e média-baixa tecnologia (BT-MBT) são muito adensados e possuem um peso grande na estrutura industrial do país. BT-MBT correspondem a dois terços da produção manufatureira e o país possui competitividade nas indústrias intensivas em insumos agropecuários, minerais e energéticos. No entanto, a categoria de alta e média-alta tecnologia (AT-MAT) possui adensamento relativamente baixo e inferior à média dos 15 países detentores dos maiores parques industriais do mundo.

Terceiro, a maioria das classes industriais apresentaram adensamento produtivo elevado, mas não é uma característica de toda a indústria de transformação conforme afirmaram Pinheiro (2014) e Canuto, Fleischhaker e Schellekens (2015). Não se pode generalizar tais afirmações uma vez que parcela substantiva das classes industriais de AT-MAT possui baixo adensamento produtivo.

Quarto, as classes industriais dos setores "eletrônicos, informática e ópticos", "farmacêutica" e "outros equipamentos de transportes" estão muito esgarçadas pelas importações. Do ponto de vista do grau de transformação industrial, partes expressivas do tecido industrial desses setores encontram-se em processo de desindustrialização avançado e assemelham-se a uma indústria de aparafusamento ou maquiladora. O setor químico possui grau de adensamento produtivo intermediário ao passar por esgarçamento produtivo significativo em poucas classes expressivas em produção industrial. Esses quatro setores são responsáveis por cerca de metade dos gastos empresariais em pesquisa e desenvolvimento (P\&D) do planeta. Dessa forma, o esgarçamento diagnosticado restringe bastante o desenvolvimento tecnológico do país.

Quinto, os demais setores de AT-MAT - automobilístico, máquinas e equipamentos e máquinas e aparelhos elétricos - possuem grau de adensamento elevado e poucas classes encontram-se fragilizadas pelas importações de insumos intermediários, porém há indícios de aumento significativo de importações de produtos acabados, finais ou intermediários.

Sexto, no caso das poucas classes de BT-MBT com maior CIICC predominaram importações não competitivas de insumos e componentes porque o país não possui capacidade de produção na quantidade $\mathrm{e}$ qualidade demandadas, principalmente devido à técnica produtiva, escassez de alguns recursos minerais (como metais preciosos), tipo de clima pouco favorável à produção de trigo, entre outros.

Portanto, o desadensamento produtivo foi mais forte nos segmentos de AT-MAT, que possuem maior qualidade em termos tecnológicos, maiores ligações entre os setores manufatureiros, alta remuneração por trabalhador, além de alta elasticidade-renda da demanda e grande dinamismo no comércio internacional. Vale mencionar que este estudo foi o primeiro que mensurou com exatidão e em maior nível de detalhamento setorial quais partes do tecido industrial são maquilas e quais estão em vias de serem maquilas, assunto que frequentemente é preocupação dos autores brasileiros, como, de Marconi e Rocha (2012a) e Sarti e Hiratuka (2018).

\section{Referências}

ANP. Edital de licitações para a outorga dos contratos de concessão para atividades de exploração e produção de petróleo e gás natural: décima primeira rodada de licitações. Rio de Janeiro: ANP, 2013. BIELSCHOWSKY, R. Investimentos na indústria brasileira depois da abertura e do Real: o miniciclo de modernizações, 1995-1997. Série Reformas Económicas No. 44. Brasília: CEPAL, 1999.

BRESSER-PEREIRA, L. C.; OREIRO, J. L.; MARCONI, N. Developmental macroeconomics: new developmentalism as a growth strategy. New York: Routledge, 2015.

BUITELAAR, R. M.; PADILLA, R.; URRUTIA, R. Industria maquiladora y cambio técnico. Revista de la CEPAL 67, p. 133-152, 1999. 
CANO, W. A desindustrialização no Brasil. Economia e Sociedade, v. 21, n. Número Especial, p. 831$851,2012$.

CANUTO, O. The high density of brazilian production chains. Disponível em: <http://blogs.worldbank.org/developmenttalk/high-density-brazilian-production-chains>.

CANUTO, O.; FLEISCHHAKER, C.; SCHELLEKENS, P. The curious case of Brazil's closedness to trade: Policy Research Working Papers No. 7228. Washington, D.C.: World Bank Group, 2015.

CASSIOLATO, J. E.; FONTAINE, P. O papel das empresas transnacionais no sistema nacional de inovação brasileiro. In: CASSIOLATO, J. E.; PODCAMENI, M. G.; SOARES, M. C. C. (Ed.). Políticas estratégicas de inovação e mudança estrutural. Rio de Janeiro: Epapers, 2015. 233-262.

CASSIOLATO, J. E.; SZAPIRO, M.; LASTRES, H. Dilemas e perspectivas da política de inovação. In: BARBOSA, N.; MARCONI, N.; PINHEIRO, M. C.; CARVALHO, L. (Ed.). Indústria e desenvolvimento produtivo no Brasil. Rio de Janeiro: Elsevier, 2015. p.377-416.

CASTILLO, J. C.; DE VRIES, G. The domestic content of Mexico's maquiladora exports: a long-run perspective. The Journal of International Trade \& Economic Development, v. 27, n. 2, p. 200-219, 2018.

CASTRO, A. B. de. A reestruturação industrial brasielira nos anos 90: uma interpretação. Revista de Economia Politica, v. 21, n. 3, p. 3-26, 2001.

COMIN, A. A desindustrialização truncada, perspectivas do desenvolvimento economico brasileiro. 257 f. Tese (Doutorado) - Instituto de Economia, Universidade Estadual de Campinas, Campinas, 2009.

COSTA, L. M. da; SILVA, M. F. de O. e. A indústria química e o setor de fertilizantes. In: SOUSA, F. L. DE (Ed.). BNDES 60 anos: perspectivas setoriais. Rio de Janeiro: BNDES, 2012. 12-60.

COUTINHO, L. A especialização regressiva: um balanço do desempenho industrial pós-estabilização. In: VELOSO, J. P. DOS R. (Ed.). Brasil: desafios de um país em transformação. Rio de Janeiro: José Olympio, 1997. p. 81-106.

DE NEGRI, F.; CAVALCANTE, L. R. (ed.). Produtividade no Brasil: desempenho e determinantes. Brasília: ABDI : IPEA, 2014. v. 1

DE NEGRI, F.; CAVALCANTE, L. R. (ed.). Produtividade no Brasil: desempenbo e determinantes. Brasília: ABDI : IPEA, 2015. v. 2

FEIJÓ, C. A.; CARVALHO, P. G. M. de; ALMEIDA, J. S. G. de. Ocorreu uma desindustrialização no Brasil? São Paulo: Instituto de Estudos para o Desenvolvimento Industrial (IEDI), 2005.

GALINDO-RUEDA, F.; VERGER, F. OECD taxonomy of economic activities based on R\&D intensity: OECD Science, Technology and Industry Working Papers No. 2016/04. Paris: OECD, 2016.

GOMES, R.; PIMENTEL, V.; LOUSADA, M.; PIERONI, J. P. O novo cenário de concorrência na indústria farmacêutica brasileira. BNDES Setorial, n. 39, p. 97-134, 2014.

HALPERN, L.; KOREN, M.; SZEIDL, A. Imported inputs and productivity. American Economic Review, v. 105, n. 12, p. 3660-3703, 2015.

HAUSMANN, R.; RODRIK, D. Economic development as self-discovery. Journal of Development Economics, v. 72, n. 2, p. 603-633, 2003.

HIRSCHMAN, A. O. The Strategy of Economic Development. New Haven: Yale University Press, 1958. IBGE - INSTITUTO BRASILEIRO DE GEOGRAFIA E ESTATÍSTICA. Matriz de insumo-produto: Brasil: 2010. Rio de Janeiro: IBGE, 2016.

JARUZELSKI, B.; STAACK, V.; SHINOZAKI, A. Global innovation 1000: software-as-a-catalyst. strategy+business, n. 85 (winter), p. 16, 2016.

MARCONI, N.; ROCHA, M. Taxa de câmbio, comércio exterior e desindustrialização precoce - o caso brasileiro. Economia e Sociedade, v. 21, n. Número Especial, p. 853-888, 2012a. 
MARCONI, N.; ROCHA, M. Insumos importados e evolução do setor manufatureiro no Brasil: Texto para Discussão do IPEA No. 1780. Brasília: IPEA, 2012b.

MARSHALL, A. Principles of economics. London: MacMillan, 1890.

MIROUDOT, S.; LANZ, R.; RAGOUSSIS, A. Trade in intermediate goods and services: OECD Trade Policy Papers No. 93. Paris: OECD, 2009.

MORCEIRO, P. C. Desindustrialização na economia brasileira no período 2000-2011: abordagens e indicadores. São Paulo: Cultura Acadêmica, 2012.

MORCEIRO, P. C. Evolution and sectoral competiveness of the Brazilian manufacturing industry. In: AMANN, E.; AZZONI, C.; BAER, W. (Ed.). The Oxford Handbook of the Brazilian Economy. New York: Oxford University Press, 2018. p. 243-265.

MORCEIRO, P. C. Penetração de insumos importados na indústria brasileira. São Paulo: Instituto de Estudos para o Desenvolvimento Industrial (IEDI), 2019.

MORCEIRO, P. C.; GUILHOTO, J. J. M. Desindustrialização setorial e estagnação de longo prazo da manufatura brasileira: TD NEREUS 01-2019. São Paulo: Núcleo de Economia Regional e Urbana da USP, 2019.

MOREIRA, M. M. A indústria brasileira nos anos 90: o que já se pode dizer? In: GIAMBIAGI, F.; MOREIRA, M. M. (Ed.). A Economia Brasileira nos Anos 90. Rio de Janeiro: BNDES, 1999. p. $293-$ 332.

NASSIF, A.; BRESSER-PEREIRA, L. C.; FEIJÓ, C. The case for reindustrialisation in developing countries: towards the connection between the macroeconomic regime and the industrial policy in Brazil. Cambridge Journal of Economics, v. 42, n. 2, p. 355-381, 2017.

OECD-ANBERD DATABASE. Analytical business enterprise research and development database ANBERD (ISIC Rev. 4). Paris: OECD, 2017.

OECD-STAN DATABASE. Database for Structural Analysis - STAN (ISIC Rev. 4, SNA08). Paris: OECD, 2018. Disponível em: <http://oe.cd/stan>.

PINHEIRO, M. C. Abertura, inserção nas cadeias globais de valor e a política industrial brasileira. In: NEVES, L. P. (Ed.). A inserção do Brasil nas cadeias globais de valor. Rio de Janeiro: Centro Brasileiro de Relações Internacionais, 2014. 2p. 34-40.

PINTEC. Pesquisa de inovação: 2014. Rio de Janeiro: IBGE, 2016.

PINTO, C. A. S. A indústria farmacêutica da América Latina: um estudo comparativo. 174 f. Dissertação (Mestrado) - Departamento de Economia, Universidade Estadual Paulista (UNESP) Júlio de Mesquita Filho, Araraquara-SP, 2014.

RAMOS, R. L. O. O comportamento das importações e exportações brasileiras com base no sistema de contas nacionais: 1980-1997: Texto para Discussão No. 95. Rio de Janeiro: IBGE, 1999.

RODRIK, D. Policies for economic diversification. CEPAL Review, v. 87, p. 7-23, 2005.

SAMPAIO, D. P. Desindustrialização e estruturas produtivas regionais no Brasil. 2015. 234 f. Tese (Doutorado) - Instituto de Economia, Unicamp, Campinas, 2015.

SARTI, F.; HIRATUKA, C. Desempenho recente da indústria brasileira no contexto de mudanças estruturais domésticas e globais. In: CARNEIRO, R.; BALTAR, P.; SARTI, F. (Ed.). Para além da política econômica. São Paulo: Editora Unesp Digital, 2018. p. 127-170.

TESSARIN, M. S. O papel da inovação, diversificação e vizinhança setorial no desenvolvimento industrial recente do Brasil. 162 f. Tese (Doutorado) - Faculdade de Economia, Administração e Contabilidade, Universidade de São Paulo, São Paulo, 2018.

UNIDO. International yearbook of industrial statistics 2017. Vienna: Edward Elgar Publishing, 2017. 